\title{
10
}

\section{Fiji's Foreign Policy and the New Pacific Diplomacy}

\section{Makereta Komai}

Fiji's suspension from the Pacific Islands Forum and the Commonwealth in May and September 2009 respectively was a major turning point in its relations with the international community. These two dramatic events sparked a change in Fiji's foreign policy, which has continued until today. Initially, these policies were formulated to circumvent what were seen as an Australia/New Zealand-led policy to isolate Fiji, and to counter the negative image and fallout created by the suspensions. Some radical thinking was put into the policy to ignite Fiji's standing in the international community in line with the government's 2006 Charter for Change. Pillar 11 of the charter requires Fiji to enlarge its foreign relations, extending beyond traditional allies to countries that respect Fiji's sovereignty and understand the needs and challenges the country was going through.

It is argued that this 'new diplomacy' has constituted a major departure from past Fiji foreign policies. This chapter demonstrates the sense in which there has been a fundamental change in the principles and practice of Fiji's foreign policy and what implications this has for Fiji's place in the region and the world. 


\section{Fiji's New Foreign Policies}

\section{Pacific Engagement and Leadership}

Fiji's foreign policies prior to 2009 were closely aligned with its bilateral relations with Australia, New Zealand and the Commonwealth, because of its history as a colony of Great Britain. A substantial part of Fiji's trade and economic relations are linked to Australia and New Zealand, and the European Union. However, the suspension of Fiji from the Pacific Islands Forum and the Commonwealth in May and September of 2009 saw a major shift in Fiji's foreign policies. Recognising the importance of regional mechanisms in global geopolitics, the first of the five strategies applied by Fiji was to maintain its presence and leadership in the Pacific region, despite its removal from the premier political body, the Pacific Islands Forum. For Fiji, the next best option was to enlist support from within the powerful sub-regional group, the Melanesian Spearhead Group (MSG), for political reforms put in place by the Bainimarama Government to return the country to democratic rule. The endorsement of the MSG was key to reclaiming some regional legitimacy within the Pacific and proving to the world that Fiji was not a pariah state (Nayasi 2013). However, in July 2010, Vanuatu's Prime Minister Edward Natapei cancelled the biennial meeting of MSG leaders because he felt that 'the group should only be chaired by an elected leader and not someone who came to power in a military coup' (Kilman 2010). He refused to hand over chairmanship of the group to Commodore Bainimarama. Despite the cancellation, Fiji convened its own Engaging with the Pacific (EWTP) meeting to replace the MSG leaders meeting, which was deferred to another date (Balawa 2013). Vanuatu's refusal to hand over the MSG chair to Fiji caused a division among the leaders of Papua New Guinea, Solomon Islands, and Vanuatu. Former Prime Minister of Papua New Guinea Sir Michael Somare was instrumental in drawing up a compromise to show support for Fiji. Sir Michael stepped in to broker the thaw in relations between Fiji and Vanuatu, and suggested Solomon Islands as a neutral venue for the handover of chairmanship of MSG and for leaders to reconcile amongst themselves. He was the only MSG leader that stood by Fiji, asking other Pacific leaders to allow Fiji to deal with its own political situation. This support is reflected in his speech at the 25th anniversary of the MSG in Noumea on 20 June. He said Fiji needed the understanding of the MSG and recognised that the 'Melanesian values of dialogue and patience have the greatest potential to bring about the change we want in Fiji'. Bainimarama ensured that Fiji was present at the Honiara meeting, because the chairmanship of the MSG was key to Fiji asserting its presence and leadership within the region (Balawa 2013). A reconciliation ceremony was held in Honiara, hosted by Solomon Islands Prime Minister Danny Philip on 15 December, where Solomon Islands handed over the MSG leadership to Fiji. 


\section{'Look North' Policy}

The second new foreign policy strategy was 'finding better partners beyond Australia and New Zealand'. As defined by Esala Nayasi, Director of Fiji's Political and Treaties Division within the Ministry of Foreign Affairs, 'these are partners who, despite the country's political situation, respected Fiji as equal and understood the policies put in place by the government to take the country back to democratic rule' (Nayasi 2013). This position was spelt out clearly by Fiji Foreign Affairs Minister Ratu Inoke Kubuabola in a speech to the Australia Fiji Business Council meeting in Brisbane in July 2013, when he said that 'Fiji no longer looks to Australia and New Zealand but to the world' (Kubuabola 2013). He said that, since 2009, Fiji had taken a 'different path' and forged new relationships with countries that understood and didn't judge the political reforms the country was going through:

Jolted from our complacency by the doors that were slammed in our faces, we looked north - to the great powers of Asia, especially China, India and Indonesia and more recently to Russia. We looked south to the vast array of nations, big and small, that make up the developing world and we currently chair the G77, the biggest voting bloc at the United Nations. And we looked to our Melanesian neighbours, to forge closer ties with them and use our collective strength to make our voices heard in global forums and secure better trading deals for us all (Kubuabola 2013).

What Ratu Inoke expounded to the Australia Fiji Business Forum was in line with the Fijian government's strategy to enhance and deepen its 'Look North' policy. Key to this strategy was the deepening of bilateral ties with China, as reiterated by Commodore Bainimarama in his 2013 state visit to Beijing. Since 2009, Commodore Bainimarama has assured the Chinese administration that Fiji will make China a key part of its 'Look North' policy (Xiaokun 2009). Political and economic support from China has enabled Fiji's economy to stabilise and the country to make political progress with its roadmap to democratic reform and elections (Balawa 2013). Instead of giving Fiji a cold shoulder, China developed closer engagement with Fiji, stepping in to fill the gaps left by Australia and New Zealand. China's position is in line with its foreign policy, which respects sovereignty and territorial integrity, non-interference in the affairs of other states, and peaceful coexistence. In May 2009, prior to Fiji's suspension from the Pacific Islands Forum, Commodore Bainimarama said: 'The Chinese authorities are very sympathetic and understand what's happening here - the fact that we need to do things in our own way.' He was the first Pacific Island leader to meet with the new Chinese President Xi Jinping, two months after he assumed office. The deepening partnership and cooperation between the two nations has raised eyebrows in Australia and New Zealand because Australia has always regarded Fiji and the rest of the Pacific as its own backyard. While Fiji was 
deepening relations with China, it also deepened ties with Indonesia and South Korea, setting up diplomatic missions in these two countries in April 2011 and July 2012 respectively.

\section{'Friends to All'}

Expanding relations meant that Fiji had to look at establishing diplomatic ties with as many countries as possible - countries that understood Fiji's political situation and did not interfere with its domestic affairs (Nayasi 2013). Prior to 2009, Fiji had established diplomatic relations with 70 countries. The new strategy required beefing up Fiji's friends globally. Nayasi stated that:

We looked at our own database and realised that we have signed diplomatic relations with only 70 countries. We saw this was something that we needed to change - first of all that we must be friends with everyone. We had to look at our comparative advantage - what we can offer rather than just depending on two countries (Australia and New Zealand).

From 2009-2013, Fiji added 63 more nations to its list of countries with diplomatic relations. According to Nayasi (2013), 'Cabinet has now given the Ministry of Foreign Affairs the go-ahead to sign diplomatic relations with the rest of the member countries of the United Nations'. Given Fiji's limited human resource capacity to set up diplomatic missions in all capitals of countries with diplomatic relations, cabinet agreed to set up diplomatic missions in all key regions of the United Nations (UN) - South Africa (Africa), Brazil (Latin America and the Caribbean), the United Arab Emirates (Middle East), and Indonesia as a key and influential nation in Southeast Asia and founding member of the Association of Southeast Asian Nations (Southeast Asia). During this process, Fiji even courted controversial friends such as Iran, North Korea, and Egypt. Nayasi said: 'As far as we are concerned, it is about respect and treating each other equally.'

At the multilateral level, Fiji actively participated in regional and international organisations, including the UN. According to Nayasi (2013):

Since we were out of the Pacific Islands Forum, our only opportunity was to revamp our participation at sub-regional and regional organisations like the Melanesian Spearhead Group, Secretariat of the Pacific Community, the Engaging With The Pacific, which is now known as the Pacific Islands Development Forum.

In 2011, Fiji chaired the Secretariat of the Pacific Community's Governing Council, the Committee of Representatives of Governments and Administrations (CRGA) and the MSG, two key positions that lifted Fiji out of the 'political and diplomatic doldrums' it found itself in after 2006 and assured its leadership and influence in the Pacific. As assessed by Nayasi (2013), 'You can clearly see the hands of Fiji in these groups - we have become an influential member at the regional level'. At the UN in New York, Fiji continued to work within the 
193-member group, securing new friends. The new strategy allows the foreign affairs office in Suva to explore benefits from being a member of an international organisation.

Fiji has actively remained engaged in the area of peacekeeping since it joined the world body. Peacekeeping is a key pillar in Fiji's foreign policies; since 1978, Fiji has derived considerable foreign revenue through remittances from soldiers on peacekeeping duties, which have provided employment to thousands of men and women. To date, UN peacekeeping has contributed over FJ\$200 million in revenue per annum, earning more than traditional sectors such as sugar and garment manufacturing. Another key aspect of Fiji's peacekeeping commitment is its strategic interests in global politics. As a result of its commitments in Sinai, Iraq, and the Golan Heights, Fiji is well regarded by super powers such as the United States. At the 68th UN General Assembly in 2013, Bainimarama assured world leaders that Fiji recognises the risks involved in peacekeeping, but that it was more than ready to provide 501 troops to Syria to shore up the UN Disengagement Observer Force (UNDOF). Peacekeeping is a source of great pride for Fiji, because it allows Fiji to make a meaningful contribution to global peace (Bainimarama 2013). For the Fiji government, 'The high standard achieved by Fijian personnel in UN peacekeeping has been a focus of national pride and has earned Fiji considerable distinction in the international community' (Ministry of Foreign Affairs and International Cooperation 2009).

An attempt by Australia in 2010 to shut Fiji out of UN peacekeeping duties was foiled even before it was tabled to the security council because of a possibility of two of the five permanent members withdrawing support for the resolution against Fiji's UN peacekeeping participation (Balawa 2013). During its term as chair of G77, Fiji was actively involved in a move within the group to introduce reforms within UN peacekeeping operations. In May 2014, Fiji and the United States were tasked to negotiate an outcome on the reforms of the UN peacekeeping operations.

\section{Significance and Implications}

\section{Global Standing}

From Fiji's perspective, the new foreign policies achieved more than they set out to do. From being an international outcast in 2009, Fiji defied all the odds to emerge as chair of the powerful G77 plus China lobby group within the UN. This achievement came about in 2012 when Fiji was elected ahead of Bangladesh to lead the 133-member group, securing more than 50 per cent of the votes in the first round of votes (Nayasi 2013). Fiji and Bangladesh were the two 
candidates from the Asia region. Nayasi revealed that Bangladesh opted for a second round of voting, but later withdrew when it realised that it would be near impossible to surpass support for the Pacific nation. A compromise was reached and Bangladesh agreed to withdraw from the race if Fiji supported its bid to be a non-permanent member of the UN Security Council. Nayasi said chairing the G77 plus China for 2013 was the pinnacle of Fiji's achievements because it became the first Pacific Small Island Developing State (PSIDS) to lead an august lobby group of more than 130 countries at the UN.

An analysis of Fiji's G77 election by Catherine Wilson argued: 'Fiji's election will give the country's leadership a chance to reach out to the rest of the region by way of consultation in order to make sure a regional voice can be heard in the international stage.' She added that the 'Pacific will have a rare opportunity to represent itself on the global stage' (Wilson 2012). In 2012, Fiji Foreign Affairs Minister Ratu Inoke Kubuabola said that Fiji's election was a 'demonstration of the confidence of the international community in Fiji to preside over the 132 member organisation in its endeavour to advance matters that are of great importance to all developing countries' (Wilson 2012). Celebrating Fiji Day in New York on 10 October 2014, Fiji's Permanent Representative to the United Nations, Ambassador Peter Thomson, said that 2013 was a significant year because it marked the first time a small island nation from the Pacific held the chairmanship of the Group of 77 plus China, the largest intergovernmental group in the UN. Ambassador Thompson explained:

Highlights so far for Fiji's Chairmanship have been its leadership leading up to and during the Special Event to follow up efforts towards achieving the Millennium Development Goals (MDGs), and the inaugural meeting of the High Level Political Forum. These were very significant events for UN Member states as they deliberate on setting the global post-2015 Development Agenda. In both events, Prime Minister Bainimarama was the lead speaker, as the Chair for the Group of 77 and China, signifying the critical importance of the Group's part in preparing for the post-2015 Development Agenda (Thompson 2013).

Not only was Fiji prominent in global affairs through its chairmanship of the G77 plus China group, the island nation was responsible for initiating discussion on behalf of PSIDS in New York to change the name of its regional grouping at the UN. Nayasi revealed the idea was borne out of discussion between him and Ambassador Thompson at the Fiji mission. The rationale behind the proposed name change was to give the Pacific the recognition it deserved as a member of the Asia Group. PSIDS represent a fifth of the membership of the Asia Group at the United Nations. However, its numbers are not reflected in the name of the group (Nayasi 2013). The Alliance of Small Island States (AOSIS) tried for the inclusion of Small Island Developing States (SIDS) to be a special category within the UN but this didn't succeed, said Nayasi. The AOSIS push was limited 
to climate change negotiations. According to Nayasi (2013), 'Fiji felt that all the issues we bring through to the UN have always been seen as a climate change and sustainable development issue. Often when it goes to the security council, it is sidelined because it lacks the politics it deserves.' Climate change and sustainable development have their own processes within the UN system. Pacific positions in these processes are represented by PSIDS, AOSIS, and G77. However, the important political manoeuvrings that moves the UN to make decisions happen at the regional grouping - where the Pacific is grouped with Asia. Nayasi reveals:

For the Pacific to elect the President of UN General Assembly, appoint judges for the International Criminal Court or any other UN elections, these decisions are allocated or divided into regional groupings. The Africa and the Asia Group are the largest groupings at the UN with 54 members each (Nayasi 2013).

In 2010, Fiji realised that if the Pacific was to have some influence over how decisions are made at the multilateral level, it must do so within its own group, the Asia Group. The idea was conceived to lobby for its inclusion in the name of the group. Fiji prepared a concept paper which it circulated to all 54 member countries of the Asia Group, including PSIDS in New York. Discussions and negotiations took a year (2009-2010) to develop the concept before it was presented to the group. Nayasi revealed:

We went bilaterally and basically convinced all the members except China and India. The concerns by these two countries was to do with if we are calling it the Asia-Pacific Group, it would mean that Australia and New Zealand will be part of the group because this is the demarcation in the UNESCAP regions. We had our discussion and we suggested two things - to call it the Asia and Pacific Small Island Developing States and do away with Asia-Pacific region (Nayasi 2013).

This was the compromise, and China and India agreed that the registered name of the group with the UN will be Asia-Pacific Islands Developing States but in terms of the everyday UN parlance, the group will be known as the Asia-Pacific group. 'For us to get that recognition means that the Pacific will now get a fair share of representation in the Asia Group' (Nayasi 2013). In September 2010, the Asia-Pacific group was formally endorsed unanimously by all members before the secretary general was officially notified. A Pacific diplomat based in New York told me that the name change was historical for the UN: 'There has never been any name change within any of the UN's regional grouping since the regions were divided in 1965. For the Pacific, especially Fiji to achieve this significant milestone is testament to Fiji's leading voice in New York on behalf of PSIDS.' Even though Fiji and the Pacific created history, Nayasi was disappointed with the support from the Pacific SIDS group: 'They thought that Fiji will not succeed. They were watching us and only came to support our effort at the very end and we were all credited for the outcome.' Fiji was the 
first PSIDS to join the Asia Group in the early 1970s. With PSIDS reflected in the group name, Federated States of Micronesia, Fiji, Marshall Islands, Nauru, Palau, Papua New Guinea, Samoa, Solomon Islands, Tonga, Tuvalu, and Vanuatu now have a prominent voice within the Asia Group.

Another boost to Fiji's global standing came in early 2012 when Brazil and India supported Commodore Bainimarama to lead the International Sugar Council (ISC) for a year. The council is the peak body for the world's largest sugar producers, representing 86 countries. Speaking after his election in London, Bainimarama said:

The election is yet another international vote of confidence in Fiji and the Government's reform program. Our chairmanship of the ISC comes on top of the extraordinary honour of chairing the G77 and China, recently chairing the EU-ACP trade negotiations, and re-joining the Pacific ACP. Fiji's standing in the world has never been higher (Bainimarama 2012).

\section{Regional Leadership}

The establishment of the Pacific Islands Development Forum (PIDF) was a significant milestone for Fiji's new foreign policy in 2009. PIDF was formed as a result of a resolution from the EWTP initiative driven by Fiji in 2010 after it was suspended from the Pacific Islands Forum meetings. The new regional body champions the implementation of the Rio +20 sustainable development agenda, SIDS development agenda under the Barbados Plan of Action and the Mauritius Strategy for Implementation, and the post-2015 development agenda. 'PIDF's choice to champion green growth will guarantee its relevance' (Tavola 2013). The inaugural meeting of the PIDF was convened by Fiji in August 2013, attended by more than 20 Pacific Island countries and territories, as well as donors and development partners. Their attendance indicates support for Fiji's leadership of an alternative regional grouping to the Pacific Islands Forum. In an interview with Islands Business magazine in October this year, respected Fijian diplomat Kaliopate Tavola said the agenda of the PIDF was 'refreshing' because it responded to the growing frustrations of Fiji and other Pacific Islands towards Australia and New Zealand. Much of that unhappiness came from undue influence on the affairs of Pacific Island countries by Australia and New Zealand (Tavola 2013). Australia and New Zealand are not part of the PIDF, but were invited as observers to the inaugural meeting in Nadi.

At the sub-regional level, Fiji was able to convince all the leaders in Melanesia, except for Vanuatu, that it could lead the organisation for two years, despite the fact that it was not a democracy. In 2011 Commodore Bainimarama took over the helm of leadership from Vanuatu, although Vanuatu Prime Minister Edward Natapei had earlier refused to hand over the chairmanship. Under 
his chairmanship, the MSG 'grew from strength to strength'. In his handover speech given on 19 June 2013 in Noumea, Bainimarama said, 'We are turning over the chairmanship of an organisation that has grown stronger, that has carved out a firmer regional and international presence, which has a clearer vision and roadmap for the future'. Some of the achievements of the MSG during Fiji's two-year chairmanship included commitment to a single market and economic union to allow for free movement of goods, services, labour and capital; implementation of the MSG Trade Agreement with the ongoing removal of tariffs for trade between MSG; the MSG Skills Movement Scheme; regional cooperation and collaboration between law enforcement agencies to tackle transnational crimes; department of peacekeeping operations to assist an MSG peacekeeping unit for peacekeeping missions; and the Melanesian Green Climate Fund to finance regional environmental initiatives. An eminent person group led by Kaliopate Tavola also carried out a review of the MSG to mark 25 years of its existence. The review sought to chart a new way forward for the sub-regional organisation.

\section{Conclusion}

The new diplomacy was a significant and radical departure from Fiji's traditional foreign policy. The decision to build new relations with every nation willing to become friends with Fiji saw some controversial nations courted, much to the disappointment of traditional allies. Some of the milestones achieved along the way were not part of the short-term objectives set out in 2009 but have become much broader, with benefits not only to Fiji but other Pacific Island countries. Fiji has now realised that the policy changes in 2009 triggered a rhetorical response that has paved the way for fundamental foreign policy change. It is now clear that these policies have survived the 2014 return to democracy and the re-establishment of relations with traditional partners.

The experiences of 2009 to date have taught Fiji many hard lessons about diplomacy and international relations. As an independent sovereign nation, Fiji has learnt not to rely too much on its traditional partners, Australia and New Zealand, but to expand its relations to any country that respects its sovereignty and does not interfere with its domestic affairs. Fiji found out that many countries were ready and willing to engage with Fiji despite the political challenges it was going through. As a result, Fiji put in place a comprehensive foreign policy to respond to the diverse responses from the international community. The new foreign policies formulated after 2009 allowed Fiji to reclaim its position as an influential PSIDS engaging constructively with the international community both at regional and global level. 


\section{References}

Ali, N.M., 2002, The Diplomacy of Micro-states, Netherlands Institute of International Relations, Clingendael.

Bainimarama, V., 2012, 'Fiji Elected as Chairman of the International Sugar Council', Fiji Government Online, 12 January. Available at: www.fiji.gov. fj/Media-Center/Press-Releases/PM-BAINIMARAMA-ELECTED-ASCHAIRMAN-OF-THE-INTERNAT.aspx.

Bainimarama, V., 2013, 'Fiji Statement at the 68th Session of the United Nations General Assembly', Fiji Government Online, 25 September. Available at: www.fiji.gov.fj/Media-Center/Speeches/STATEMENT-BY-COMMODOREJOSAlA-VOREQE-BAINIMARAMA-P.aspx.

Bainimarama, V., 2013, 'PM Bainimarama Address at the Opening of the 19th MSG Leader's Summit to Handover Chairmanship', Fiji Government Online, June 19. Available at: www.fiji.gov.fj/Media-Center/Speeches/PMBAINIMARAMA---ADDRESS-AT-THE-OPENING-OF-THE-19T.aspx.

Balawa, S., 2013, 'Survival Diplomacy', interview with M. Komai, 19 September.

Davis, G., 2012, 'Australia's Humiliating Backdown Over Failed Fiji Foreign Policy', Pacific Scoop, 1 August. Available at: pacific.scoop.co.nz/2012/08/ australias-humiliating-backdown-over-failed-foreign-policy-on-fiji/.

Fraenkel, J., 2013, 'How to respond to the impasse in Fiji?', Devpolicy, 15 August. Available at: devpolicy.org/how-to-respond-to-the-impasse-infiji-20130815/.

Kilman, S., 2010, 'Vanuatu's Kilman off to MSG Meeting in Honiara', interview with RNZI, 14 December.

Kubuabola, Ratu I., 2013, Speech at the 20th Australia Fiji Business Forum, Brisbane, 29 July.

Maclellan, N., 2006, Fiji, the War in Iraq, and the Privatisation of Pacific Island Security', APSNet Policy Forum. Available at: nautilus.org/apsnet/061lamaclellan-html/.

McNamara, K., 2009, 'Voices from the Margins: Pacific ambassadors and the geopolitics of marginality at the United Nation', Asia Pacific Viewpoint 50(1), pp. $1-12$.

Ministry of Foreign Affairs and International Cooperation, 2009, 'Fiji's Foreign Policy'. Available at: www.foreignaffairs.gov.fj/foreign-policy. 
Nayasi, E., 2013, 'Fiji's Foreign Policies in 2009', interview with author, 17 September.

Tavola, K., 2013, 'Fiji's PIDF Here to Stay', Islands Business October. Available at: www.islandsbusiness.com.

Thompson, P., 2013, 'FIJI PRUN'. Available at: www.fijiprun.org/news-releases.

Watson, A., 1982, Diplomacy: The dialogue between states, Eyre Methuen, London.

Wilson, C., 2012, 'Fiji's Leadership of G77 a "rare opportunity" for the Pacific", PACNEWS, 10 October. Available at: www.pina.com.fj.

Xiaokun, L., 2009, 'Fiji to make China key focus of new policy', China Daily, 20 May. Available at: www.chinadaily.com.cn/kindle/2013-05/30/ content_16547846.htm. 
This text is taken from The New Pacific Diplomacy, edited by Greg Fry and Sandra Tarte, published 2015 by ANU Press, The Australian National University, Canberra, Australia. 